\title{
Research on Innovation and Entrepreneurship in the Transformation of Applied Technology University
}

\author{
Rui Han ${ }^{1}$, Yanlin Yin ${ }^{1}$ \\ ${ }^{1}$ Heilongjiang University of Technology, Jixi, Heilongjiang 158100
}

Keywords: applied technology university; innovation and entrepreneurship; transformation and training

\begin{abstract}
Faced with the new situation, the socio-economic development needs innovative talents. The problem of innovation and entrepreneurship education for undergraduates in applied technology universities is particularly important. At present, there are many problems in this area. This paper mainly analyzes problems, the status quo and reasons of innovation and entrepreneurship education, trying to explore effective countermeasures for the development of innovative entrepreneurship education in applied technology universities.
\end{abstract}

\section{Introduction}

At present, the application-oriented colleges and universities provide services for regional economic development and foster high-quality applied talents with innovative entrepreneurial spirit. It is particularly important to actively carry out innovation and entrepreneurship education for college students. On the one hand, it can both improve the quality of personnel training and effectively promote schools. Development; On the other hand, it can better serve local economic development.

The concept of innovation and entrepreneurship education was proposed by UNESCO in 1989 . Subsequently, China's Tsinghua University and other universities spontaneously explored innovation and entrepreneurship education, setting off an upsurge of innovation and entrepreneurship education in China. Most colleges and universities actively respond to the country's call and attach importance to entrepreneurship education for college students. The entrepreneurship education in some key universities in our country has experienced unprecedented rapid development and achieved fruitful results. Innovation and entrepreneurship education is the aim of the school to improve the level of independent innovation and entrepreneurship of students in ordinary institutions of higher learning. It aims to cultivate students' innovative spirit and entrepreneurial ability needed in the job search process, and carries out a series of innovative entrepreneurial practices within the school. In order to achieve the goal of improving the quality of innovation and entrepreneurship education and better serving the socio-economic development. At the same time, with the increase of graduates' employment pressure, college students' innovation and entrepreneurship provide a good solution to ease employment pressure to a certain extent, and become an effective way for some college graduates to solve their work problems. As an important part of the higher education system, applied-type colleges and universities have the same attributes as general undergraduate colleges, but there is still a gap between their level of education and the strength of teachers in comparison with research-oriented universities. Faced with the prevailing employment pressure in the society, the current status of graduates and the cruel reality, graduates of applied universities are in a disadvantageous position in the fierce employment environment. Therefore, strengthening innovation and entrepreneurship education is a must. Schools should learn from the conditions of their own education and the strength of teachers to absorb the experiences and lessons of innovation and entrepreneurship education in other institutions, strengthen the construction of teachers, and create innovation and entrepreneurship education that is characteristic of this school, so as to cultivate high-quality professionals [1]. 


\section{Problems in Innovation and Entrepreneurship Education in Applied Technology Universities}

For the so-called innovation and entrepreneurship, many college students have an ambiguous understanding, and even some teachers are unclear in concept. They believe that teaching students have opened companies and misunderstood the orientation of talents for innovation and entrepreneurship training. There are also some viewpoints that entrepreneurship is the best strategy for employment and students are considered Without going out of school, they do not have the ability to innovate and start a business. They think that they are taking the form and going through the motions.

At present, innovation and entrepreneurship education in many colleges and universities has not been included in the teaching plan as a compulsory course, lack of a systematic teaching system, the establishment of courses less, less school hours, can not complete the teaching content, achieve the goal of personnel training. There is no uniform professional teaching material support. Most of the lectures are shallow and not specific enough. Most colleges and universities are mainly taught by theory, lack of practical training, and related entrepreneurial cases. Most of them are celebrity effects. Each person has its own case. Targeted, can not be good to mobilize the entrepreneurial thinking of college students, the effect of teaching is not ideal [2].

Because the innovation and entrepreneurship education started late in colleges and universities, there is no full-time teacher who specializes in related education. Most of the schools are counselors or part-time employees who work in entrepreneurial and employment-related departments. Their teaching content is also obtained through out training. No systematic training, no practical experience and experience in innovation and entrepreneurship can only be learned a little, speak a little, and can only theoretically teach in the teaching process, lack of pertinence, lack of guiding significance, and difficult to expand into practice space. Cannot achieve the ultimate goal of guiding and guiding students in innovation and entrepreneurship.

\section{The Significance of Innovation and Entrepreneurship Education for College Students in Applied Technology Universities}

At present, the competition in higher education institutions and the strength of teachers has become increasingly fierce. The pursuit of the characteristics of running schools that belong to this school has become a magic weapon for universities to win in fierce competition. No matter whether it is a research-oriented college, an applied-type college or a private college, it will highlight the school-running characteristics as an important task for the survival and development of the university. For example, research-oriented universities use research results as the characteristics of running schools, normal universities and colleges take teaching and education as the characteristics of running schools, and higher vocational colleges emphasize outstanding professional skills as the characteristics of running a school. Some key integrated universities take into account research and education in the aspects of school characteristics. . Application-oriented colleges and universities should get a place in the education system of universities and colleges in our country, but also determine their own characteristics of running a school according to their own level of education and the strength of teachers, but the characteristics of the application of undergraduate colleges is no doubt highlighting its "Application" features. By changing the traditional concept of education, from the perspective of students' future career development, the importance of students' application and practical abilities, carrying out innovation and entrepreneurship education, and fostering the entrepreneurial spirit of college students coincide with the purpose of running the university and the characteristics of its application. This coincides with the fact that it will not only contribute to enhancing core competitiveness, but also contribute to the continuous improvement of the quality of personnel training and the continuous realization of innovation and development [3].

The school-running characteristics of applied-type undergraduate colleges are centered on "application", which requires schools to pay attention to the improvement of students' practical ability and application ability in personnel training. However, at present, most institutions of higher 
education still tend to focus on students' professional knowledge and ignore the students' ability to practice in the learning process. As a result, students' application ability, practical ability, and innovation and entrepreneurial ability are not improved. This is a serious violation. The Characteristics of Running an Application-oriented University with the Core of "Application". College students' innovation and entrepreneurship education not only requires students to have systemic professional knowledge in the classroom, but also requires students to cultivate their own innovative thinking, professional skills, and innovative abilities in the practice process, and highly integrate the learning content of classroom knowledge with extracurricular activities. Based on the study of professional courses, guide students to participate in entrepreneurial practice and achieve the unity of "theoretical knowledge learning" and "entrepreneurial practice". In the whole process of entrepreneurship education, students are both the main body of practice and the main body of innovation. Through learning, they not only help improve students' practical ability, but also have great significance for improving the overall quality of students [4].

The increasing number of university graduates, the incentive for employment competition, and the increasing difficulty in employment in society have become the main employment facts in recent years. Although the state took measures to protect college graduates from employment difficulties, facing a large number of graduating groups each year, combined with the status quo of government agencies, enterprises, and government organizations to decentralize their powers and layoffs, a series of employment protection is tantamount to a drop in salary. Providing adequate and good employment opportunities for university graduates, but also unable to fundamentally solve the employment problems of university graduates, this will inevitably lead to the frustration of some university graduates who have just come out of the ivory tower, and the failure of the job search experience again and again. Make their self-confidence frustrated and do nothing. In the situation where the employment problem cannot be solved, some college students are increasingly demanding for entrepreneurship. Under the premise of economic conditions and external factors, some college graduates may choose to start their own business as another type of employment and achievement. The main way of value. Through entrepreneurship education, some students understand the relevant entrepreneurial knowledge and encourage them to join the army of contemporary innovation and entrepreneurship. They can provide the foundation for future entrepreneurial roads and relieve the employment pressure while also helping college students achieve their ideals of life.

\section{Strategies and Suggestions of Innovation and Entrepreneurship Education for College Students in Applied Technology Universities}

Philosophy is the forerunner of action. First of all, it should update the concept of talent cultivation, innovate the model of talent cultivation, and change to cultivate a comprehensive "innovation and entrepreneurial” talent training model. All along, our country's college education is the teaching of traditional theories, single model training, ignoring the development of students' creative thinking ability, ignoring the overall development of students. At present, transitional colleges and universities of applied-type need to cultivate all-round development of comprehensive talents adapted to economic development. They urgently need to change their concepts. They must clearly understand that the essence of innovation and entrepreneurship education is quality education, and focus on cultivating students' sense of innovation, entrepreneurial ability and practical ability, improve students' comprehensive quality [5].

The cultivation of college students' awareness of innovation and entrepreneurship depends in part on themselves and on the other hand, it comes from educators. At present, there are few applied-training undergraduate colleges that specialize in innovation and entrepreneurship education. Therefore, building an excellent and experienced faculty is an urgent issue to be solved. The field of innovation and entrepreneurship education is comprehensive, practical, and fast to update, so teachers are required to establish innovative entrepreneurship education concepts and accomplishments, thereby affecting students, but also have a solid theoretical basis, participate in regular training, and learn more experience, and explore flexible classroom teaching models to 
enhance teacher-student interaction and allow students to better understand the theory of innovation and entrepreneurship. On the other hand, it is necessary to strengthen the training of practical ability. There are planned and targeted teachers who are engaged in innovation and entrepreneurship education to relevant companies to conduct training, experience the entrepreneurial process, enrich experience, strengthen the construction of "dual-qualified" teachers, and can also hire Successful entrepreneurs and typical entrepreneurs come to the school for part-time work or lecture training to guide students through entrepreneurship and achieve better results. Developed countries in Europe and America started earlier in innovation and entrepreneurship education, while our country started late from the government level and the university level, and is still in the development stage. As an application-oriented undergraduate college, most of its funding sources depend on local financial allocations. Therefore, it is first necessary to increase policy support and financial support from the government level to provide facilities for college students to innovate and start businesses, and to promote the transformation of project achievements to form a benign environment. Development situation. In the new era of rapid development of the knowledge economy, innovative colleges and universities in applied colleges and universities are faced with a new situation of rapid development, with great responsibility. It is necessary to adjust from the aspects of curriculum reform, teachers, entrepreneurship, and the social environment, and cultivate complex talents with high overall quality and comprehensive development to serve local economic development.

\section{Conclusion}

As innovation and entrepreneurial talents are favored in the society, innovation and entrepreneurship education has become an important way to ease employment pressure in most of the applied-type colleges and universities, and the innovation and entrepreneurship education of college students has been improved to enhance core competitiveness and improve students' practical ability. Relieving employment pressure and promoting the development of students themselves are extremely important. However, the current innovation and entrepreneurship education in applied-type undergraduate colleges still has problems such as lack of understanding, imperfect discipline construction, incomplete teacher resources, and serious disconnect from practice. Related schools pay attention to innovation and entrepreneurship education courses, build a complete teaching system, and strengthen The construction of teaching staff, improvement of incentive mechanisms and other measures to take measures to improve students' ability to innovate and entrepreneurship, provide more opportunities for college students to start their own businesses, and at the same time provide sufficient foundation for the application of undergraduate colleges to do a good job in entrepreneurship education. ready.

\section{Acknowledgements}

Jixi Social Science Research Project (Key Project), Project Number: 2017JSK011

\section{References}

[1] Li Qifeng. Analysis of the Path of Implementation of Innovation and Entrepreneurship Education for College Students [J]. Chinese Business Theory, 2017 (28): 36-39.

[2] Wu Fangpeng. Application-oriented undergraduates' entrepreneurial innovation training mode [J]. Chinese Journal of Education, 2015(S2): 278-279.

[3] Li Jing. The current situation and countermeasures of innovation and entrepreneurship education in domestic universities [J]. Chinese Training, 2016 (14): 45-46.

[4] Xu Detao. University students' innovation and entrepreneurship education [D]. Jinan: Shandong University, 2013.

[5] Feng Rui. How can college counselors carry out innovation and entrepreneurship education for undergraduate college students[J]. Rural Economy \& Technology, 2016 